\title{
Psychosocial reintegration process in patients who receive maintenance treatment with methadone: A qualitative analysis
}

\author{
David B. Diaz-Negrete, ${ }^{1}$ Marina Velázquez-Altamirano, ${ }^{2}$ José L. Benítez-Villa, ${ }^{1}$ Carmen Fernández-Cáceres ${ }^{3}$
}

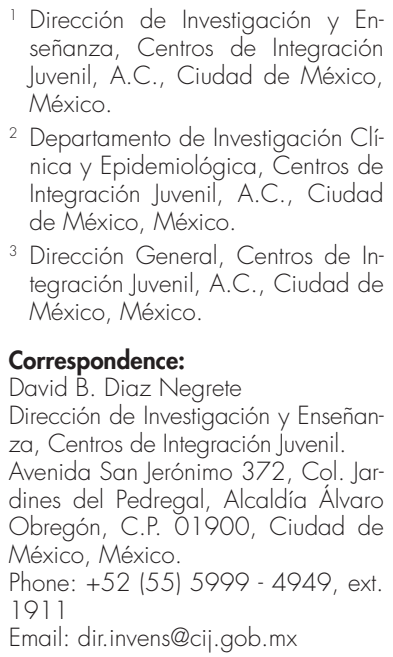

2 Departamento de Investigación Clínica y Epidemiológica, Centros de Integración Juvenil, A.C., Ciudad de México, México.

3 Dirección General, Centros de Integración Juvenil, A.C., Ciudad de México, México.

\section{Correspondence:}

David B. Diaz Negrete

Dirección de Investigación y Enseñanza, Centros de Integración Juvenil.

Avenida San Jerónimo 372, Col. Jardines del Pedregal, Alcaldía Álvaro Obregón, C.P. O1900, Ciudad de México, México.

Phone: +52 (55) 5999 - 4949, ext. 1911

Email: dir.invens@cij.gob.mx

Received: 11 April 2019

Accepted: 3 June 2019

Citation:

Diaz-Negrete, D. B., Velázquez-Altamirano, M., Benítez-Villa, J. L., \& Fernández-Cáceres, C. (2019). Psychosocial reintegration process in patients who receive maintenance treatment with methadone: A qualitative analysis. Salud Mental, 42(4), 173-184.

DOI: $10.17711 /$ SM.0185-3325.2019.023

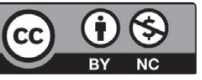

\begin{abstract}
Introduction. The evaluation of methadone maintenance programs reports generally positive outcomes. Objective. To explore the psychosocial factors that contribute to achieve treatment goals even when patients live in conditions of precariousness and exclusion. Method. Qualitative study of multiple cases, with a sample of 12 interviews with patients participating in a maintenance and detoxification program with methadone; a thematic and discursive-narrative analysis was undertaken. Results. We identified the predominance of a typical discursive scheme composed of clearly differentiated narrative segments: previous conditions, establishment of a relationship with the therapeutic system, process of adjustment as a part of treatment and social reintegration. Two main themes were also identified: addiction and dealing with substances, and the problem of normative integration; there was also an experience of acceptance and recognition that constitutes a central factor for treatment. Discussion and conclusion. These findings are discussed in light of the disaffiliated conditions of people using injected heroin and the need to consider psychosocial and normative adjustment as a relevant factor for treatment and social reintegration, which leads to the suggestion to include psychotherapeutic interventions to accompany and reinforce the process.
\end{abstract}

Keywords: Social reintegration, social stigma, heroin dependence, methadone, qualitative research.

\section{RESUMEN}

Introducción. La evaluación de los programas de mantenimiento con metadona reporta, en general, resultados positivos. Objetivo. Explorar factores psicosociales que contribuyan al logro de los objetivos del tratamiento, incluso cuando los pacientes se encuentran en condiciones de precariedad y exclusión. Método. Estudio cualitativo de casos múltiples, con una muestra de 12 entrevistas con pacientes participantes en un programa de mantenimiento y deshabituación con metadona; se realizó un análisis discursivo-narrativo y temático. Resultados. Identificamos el predominio de un esquema discursivo típico compuesto de segmentos narrativos claramente diferenciados: condiciones previas, vinculación con el sistema terapéutico, proceso de ajuste al interior del tratamiento y proceso de reintegración social. También se identificaron dos ejes de articulación temática: la adicción y el manejo de sustancias, y el problema de la integración normativa; hubo además una experiencia de aceptación y reconocimiento que constituye un factor central en el tratamiento. Discusión y conclusión. Estos hallazgos se discuten a la luz de las condiciones de desafiliación del usuario de heroína y de la necesidad de considerar el ajuste psicosocial y normativo como un factor relevante para el tratamiento y la reintegración social, lo que lleva a sugerir que los programas incluyan componentes psicoterapéuticos con el objeto de acompañar y reforzar efectivamente el proceso.

Palabras clave: Reintegración social, estigma social, dependencia a la heroína, metadona, investigación cualitativa. 


\section{INTRODUCTION}

People using opioids such as heroin, a substance that usually involves intravenous injection, not only face serious health risks, but are one of the most deprived, marginalized, and stigmatized group of people who use drugs (United Nations Office on Drugs and Crime [UNODC], 2018).

To treat these patients, the use of opioid replacement therapies has been recommended as the first-line choice (Bruneau et al., 2018; World Health Organization, 2009), of which methadone maintenance treatment (MMT) has been recognized as one of the most cost-effective interventions in managing dependence (Mattick, Breen, Kimber, \& Davoli, 2009).

Since its inception, MMT has been evaluated in terms of pharmacological safety and medical benefits (Joseph, Stancliff, \& Langrod, 2000). In this respect, it is known that MMT reduces the morbi-mortality attributable to the use of opioids, the costs derived from the associated crime, and the transmission of infectious-contagious diseases such as acquired immunodeficiency syndrome and hepatitis C (Harris et al., 2006), thus contributing to improve the social functioning and quality of life of patients (Khalatbari-mohseni et al., 2019; Fernández Miranda, 2005).

MMT has been successfully implemented in various clinical settings (Harris et al., 2006) and typically incorporates some form of psychological intervention designed to promote the rehabilitation and social reintegration of patients (Brands, Blake, \& Marsh, 2003). It has been emphasized that the incorporation of such elements for social reintegration should be an integral component of addiction treatment (Verster \& Solberg, 2003), in order to address the social precariousness that affects people using drugs in general and intravenous heroin in particular (Solal \& Schneider, 1996).

Although it has been documented the process of social reintegration is linked to various factors associated with greater therapeutic adherence, such as patients characteristics, individual needs, expectations, and satisfaction with treatment effects (Singh, Shrestha, \& Bhandari, 2014). The aim of this paper is to contribute to the understanding of the process through an emic analysis of the forms of discursive expression whereby patients with heroin dependency problems who participate in an MMT describe and signify their experience.

\section{METHOD}

\section{Study design}

Qualitative study of multiple cases, through which we seek to obtain an ideographic understanding of the topic of study based on the experience and meanings given by the par- ticipants (Creswell, 2007). We assume a constructionist perspective which presupposes that the way members of a society interpret the reality in which they live contributes decisively to shaping this reality.

This study was conducted in 2012 as part of an evaluation of the Methadone Maintenance and Detoxification Treatment (MMDT) given at a Heroin Treatment Center (HTC) of Centros de Integración Juvenil, in the city of Tijuana.

\section{Participants}

Study participants included patients of both sexes who were receiving maintenance treatment with methadone, who were over 18 years old and who agreed to participate in the study.

The sample was integrated by convenience but sufficient to get theoretical saturation.

\section{Sites}

The MMDT offered an opioid replacement alternative for people using injected heroin in hospital or outpatient treatment, seeking to reduce the damage associated with use and improve the living conditions of patients. It consisted of three components: 1) detoxification, designed to stop opioid poisoning through safe medication with methadone; 2) maintenance, consisting of stabilization with methadone to prolong abstinence; and 3) rehabilitation, aimed at promoting the reintegration of patients into the family and social environment, for which it incorporated psychotherapeutic interventions focused on preventing relapses and developing social skills, through individual, group and family inter ventions. These activities were voluntary and made available to patients on a regular basis.

\section{Procedure}

Interviews were conducted at the HTC treatment facilities, individually, face to face, and audio-recorded. Identification data were recorded, including age, sex, and pseudonyms selected by the respondents. The interview guide was designed to explore the experience of patients in the program, the process of heroin substitution, implications for their health and psychological state, the situation regarding their family and social integration, and the perceived quality of the service. To this end, open questions were formulated: What has your experience of the program been like? What changes have you experienced in the treatment? How have you felt?, and so on. The interviews were conducted by two researchers with field experience, according to general technical guidelines previously agreed upon, with the necessary conditions of silence, privacy, and safety. The interviews lasted between 40 and 60 minutes and were conducted in a single session. 
Most were transcribed with a naturalistic approach, with an intermediate level of editing (Farías \& Montero, 2005), following the grammatical conventions of Spanish, but with respect for idiosyncratic expressions, phrases, and other characteristics of spoken language. However, one case could only be retrieved through an interview report prepared as a content report. With regards this English version, we could say that even when many idiosyncratic linguistic twists and connotations were lost in translation, it sufficiently reflects the denotative content of the speech.

The "textualization" of the interview segments included in this paper was undertaken with strict adherence to the recovered transcripts, although occasionally, when the content allowed, we took the liberty of incorporating fragments from different moments of the interview or making adjustments to ensure the consistency and congruence of the material or simplify its presentation, eliminating interpolations or excessive repetitions.

Following the review of the transcribed interviews, two cases that failed to offer adequate discursive density were discarded, as a result of which the sample compiled 12 interviews of heroin-dependent patients, 11 men and one woman (Nicté), with the next characteristics (Table 1):

\section{Data analysis}

The materials were analyzed in two steps, through narrative and thematic analysis methods. First, we selected -on the basis of the criterion of narrative density- an interview segment as an example that would make it possible to establish a first "diagram" of the discursive contents of interest. According to Agamben (2010), an "example" or "paradigm" is a singular element of a class of objects that it, while be- ing subtracted as example, contributes to constitute. When taken as an example, a specific case allows to define, in its singularity, the intelligibility, structure, and conditions of existence of the whole class (Castro, 2012).

From the analysis of this segment, and according to the logic of real life events depicted in narration (Bal \& Van Boheemen, 2009), we identified four clearly differentiated narrative sequences: a) drug abuse and social exclusion before treatment, b) construction of the relationship with the therapeutic system, c) therapeutic process, and d) ongoing social reintegration. We also constructed, through standard coding procedures (Coffey \& Atkinson, 2003), a first set of thematic categories, including two dimensions of global semantic articulation, related to how to deal with drugs, and to the expected social reintegration.

Subsequently, as the core phase of analysis, we proceeded, through thematic analysis (Aronson, 1995; Braun \& Clarke, 2006; Mieles Barrera, Tonon, \& Alvarado Salgado, 2012), to identify patterns of meaning that would provide an understanding of the corpus of study, and would allow us to corroborate, expand, and adjust the initial system, of codes and categories. This led us to a last set of semantic-discursive units, i.e., significant elements that share common spheres of meaning and maintain relationships of implication, causality, contradiction, complementarity, and so on. These discursive units distributed distinctly throughout the four narrative sequences, and according to the two transversal axes of discursive and semantic articulation (Figure 1). A sample of these discursive units is presented in the tables.

The joint analysis of materials, the comparison of reviews carried out separately, and a constant discussion of the categories in development enabled us to achieve a rea-

Table 1

Patients characteristics

\begin{tabular}{|c|c|c|c|c|c|c|c|}
\hline Case (pseudonym) & $\begin{array}{c}\text { Age } \\
\text { (years) }\end{array}$ & $\begin{array}{c}\text { Age of drug } \\
\text { use onset } \\
\text { (years) }\end{array}$ & $\begin{array}{c}\text { Age of heroin } \\
\text { use onset } \\
\text { (years) }\end{array}$ & $\begin{array}{l}\text { Substances used } \\
\text { in last } 30 \text { days }\end{array}$ & $\begin{array}{c}\text { Methadone } \\
\text { initial dose } \\
(\mathrm{mg})\end{array}$ & $\begin{array}{l}\text { Methadone } \\
\text { stabilization } \\
\text { dose (mg) }\end{array}$ & $\begin{array}{c}\text { Lapse in metha- } \\
\text { done maintenance } \\
\text { treatment }\end{array}$ \\
\hline$\overline{\text { Ozzy }}$ & 22 & * & * & TB, MJ, MTH, HR, & * & * & 1 week \\
\hline Nicté & 28 & 12 & 16 & TB, HR & 40 & 40 & 2 years \\
\hline Águila & 31 & 11 & 20 & ** & 80 & 120 & 6 months \\
\hline Ángel & 33 & * & * & TB & * & * & 6 months \\
\hline Smiley & 33 & 12 & 18 & ** & 110 & 110 & 7 weeks \\
\hline Juan & 36 & 10 & 22 & $* *$ & 80 & 80 & 2 years \\
\hline Johny & 39 & 17 & 26 & TB, MJ, HR & 50 & 50 & 2 months \\
\hline Matus & 41 & 12 & 16 & TB & 60 & 100 & 2 years, 10 months \\
\hline Junior & 42 & 10 & 23 & MJ, MTH, BZ, HR & 130 & 100 & 2 years \\
\hline Memo & 45 & 10 & 19 & MJ, HR & 40 & 40 & 1 year, 6 months \\
\hline Meño & 45 & 12 & 22 & $\mathrm{HR}$ & 100 & 100 & 6 months \\
\hline Rogelio & 45 & 15 & 26 & TB & 80 & 90 & 2 years \\
\hline
\end{tabular}

Notes: *(no information avialable), ${ }^{* *}$ (no consumption reported). TB: tobacco; MJ: marijuana; MTH: metanphetamines; HR: heroin; BZ: benzodiazepines. All participants reported injecting heroin. 
Axes of semantic articulation

Social and normative integration

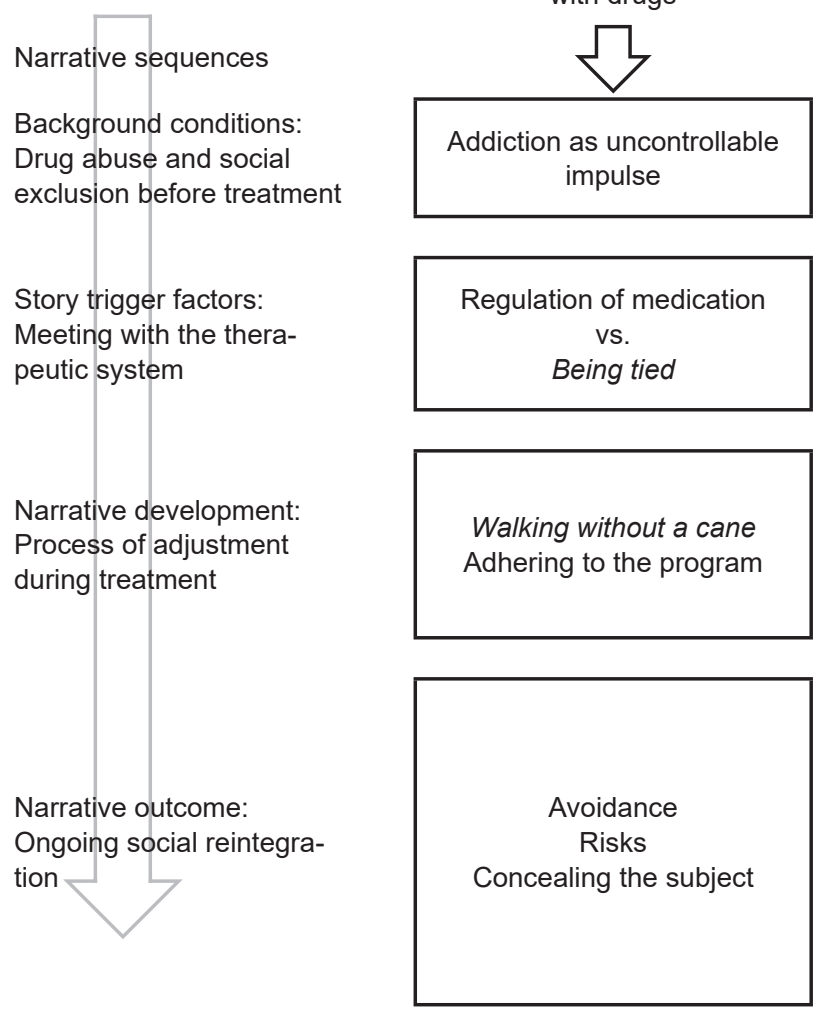

Addictions and dealing with drugs

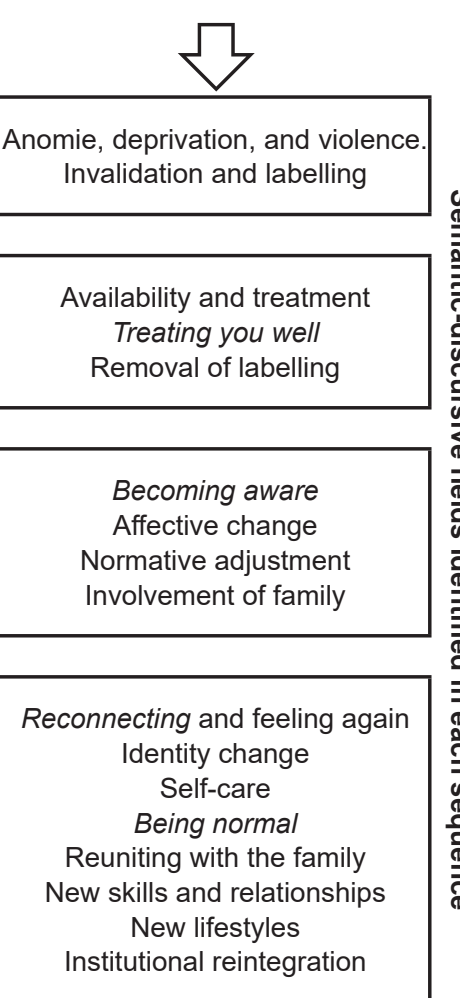

Figure 1. Structuring of discursive elements in the narration of the adjustment and social reintegration process by patients participating in a maintenance and detoxification program with methadone.

sonable level of "theoretical saturation", with enough iterations and variations of discursive enunciates within our two main thematic axes. The analysis was performed using a text processor.

\section{Ethical considerations}

According with the regulatory policies, this study was undertaken in compliance with ethical principles of voluntary participation and confidential data management. Additionally, obtained approbation by the institutional ethical committee.

\section{RESULTS}

\section{Paradigm for reading and first categories system}

The following is an excerpt from the interview with Matus, a 41-year-old patient who had a criminal record for attempted murder and possession of weapons used by the army, who had lived for years in poverty, and had been in MMDT for two years, participating in individual and group psychotherapy:
"My experience here has been very good; they have helped me. When I arrived, I was in a r eally bad state... The first twelve months I spent here I was in a bad state ... because I used methadone, I used pills, I used crystal, in other words, I used a hotchpotch of things. In my individual therapies, even Dr. V. once said to me: Why do you come here? Because I used to fall asleep. She used to tell me: Because you're just taking up a place... And there are people who really want to get better. And I think it was the disease itself, I was in a bad state. But she was patient with me, she guided me, she started giving me books ... to read, very good books, she told me: This can motivate you. And, for some reason, she hit the nail on the head.

Then there was Dr. T., who gave me the group sessions, and was also very patient with me. I remember once, I dunno, he said ... I got up very angrily, I was annoyed by something he said, and he calmly replied: No, look, it's your illness that makes you react like that, and that made me think: Why ... if I'm so rude, do they keep treating me well? And that's when I started to pay more attention, and I said: There's no way they can be more worried more about me than I am. They told me things, you know, because... they said: Look, you're gap toothed ..., and that happened to me because I wasn't clean, I did not bathe, I was always dirty. I thought they were just saying that to annoy me, but ... I began to understand people's facial expressions and I saw that they weren't saying that because of discrimination, they were telling me that because they cared. 
So, I started to take time, and... I do not know if it was because they repeated it to me so often... I started to get my teeth fixed and then I began ... And the doctor, who saw I liked to read, said: Why don't you go to school? I hadn't finished middle school, I have just completed it ... Now I look cleaner and my family is more respectful to me..."

In this fragment, we can identify elements of a typical narrative structure that links moments or sequences of a process which, beginning with an initial condition, is oriented through a series of episodes and actions as a result of achieving a new state of things. It is a structure of achievement and improvement in which substance abuse is postulated as the initial condition: "When I arrived, I was in a really bad state... The first twelve months I spent here frankly I was in a bad state... because I used methadone, pills, crystal...," with a negative connotation: "I used a hotchpotch of things." This starting point is altered by two factors of change, resulting from the intervention of the therapeutic system, which refer to elements of a clearly normative nature. First, a call to take responsibility: “...Dr. V. once said to me: 'Why do you come here?' .... She used to tell me: "Because you're just taking up a place... And there are people who really want to get out of the disease." Second, the fact that the interviewee did not receive the discriminatory treatment and rejection he expected: "But she was patient with me, she guided me, and started giving me books," "Dr. T. was also very patient with me."

As a result of the "trigger" effect of these two factors, the story takes place through various elements of action:

- Becoming aware: "I was in a bad way."

- Giving oneself time: "Then I started to spend time on myself."

- Assuming responsibility: "I started paying more attention to things..."

- Becoming aware of the acceptance of the therapeutic team: "There's no way they can be more worried about me than I am; I began to understand facial features; I understood that they weren't saying this to me out of discrimination."

- Change of self-image: From: "If I'm so rude" or "I did not bathe," "I was always dirty," to: "Now I'm cleaner."

This set of actions would eventually lead to outcome conditions, related to: a) returning to a school setting: "She said: 'Why do not you go to school?' I hadn't completed middle school; I have just finished it...;" b) self-care: "I began to get my teeth fixed ...;" and a possible change in family relationships: "And my family is more respectful to me ..."

This yielded four narrative sequences (background, triggers, narrative action, and outcome) referring to four distinct phases in the treatment and reintegration process:

1. Background conditions of participation in the MMDT that include an initial state with negative connotations (in the case of Matus, an explicit reference to substance abuse), which is therefore expected to change.

2. Story trigger factors, which in this case allude to the first and subsequent meetings with the members of the therapeutic system.

3. Process of adjustment throughout the treatment, comprising a range of actions and measures taken to achieve change.

4. Social reintegration, which includes, as an outcome, a redefinition of self-image and the relationship with drugs, environment, and agencies of conventional normative society.

\section{Thematic analysis}

In the course of the interviews, the four sequences identified do not necessarily unfold in a linear and clearly differentiated way, but may be confused, inverted, repeated, and so on. In any case, they offer a logical framework that allows for the analysis of the remaining cases according to a typical articulation of a dominant social discourse.

\section{Background conditions}

The conditions described before participation in the MMDT point in two directions. First, a topic related to addiction, around which an initial semantic and discursive field is formed defining addiction as being related to submission to a compulsive, irrepressible need (Table 2, segments 2.1.1, 2.1.3). It also refers to an idea of an exceeding, overflowing use, with a combination of various "hard" drugs (2.1.5). At the same time, meanings of insensitivity, anesthesia, or lethargy are attributed to it: "Being in a bubble" (2.1.1, 2.1.2, 2.1.4) and a disturbing effect of "nerves" and "cold turkey" (5.2.3 and 5.2.8). It is also associated with images of "getting hooked", signified as impotence (2.1.4); and of heroin as a "cane" enabling one to walk; of the addict as a "drowsy" subject, "enthralled" by the drug (2.1.3, 2.1.4); and of "reaching rock bottom" as a profound moral and spiritual collapse (2.1.6). Lastly, addiction is linked to relapses, attributed to depression, family and personal problems (2.1.7) and, above all, to the influence of other addicts $(5.1 .3,5.1 .4)$.

At the same time, it is possible to distinguish, also as an antecedent, social deprivation, including violence and anomie. This involves the prevalence of situations of extreme precariousness and destitution (2.2.1, 2.2.2), discrimination (2.2.3), and violence that goes from the family (2.2.4) to criminal behavior (2.2.5). However, the most frequently observed elements, constituting a central semantic field, refer to invalidation and labeling, with situations such as discredit within the family (2.2.6) and police harassment (2.2.7), whose reiteration affects the internalization of rejection and the production of a profound regulatory gap (2.2.8). Both discursive fields: depri- 
Table 2

Segments related to conditions prior to treatment

Axis: Addiction and dealing with substances

2.1.1. I used to get up to use drugs and then I had to chase money, money, money, and I didn't have time for my hygiene, for bathing, because that was a waste of time ... Everything I earned I spent on drugs, however much, or kept it for another dose ... I was numb, anesthetized ... [Eagle, 31 years old].

2.1.2. With heroin, I was like in my bubble ... In my addiction I only thought about how l'd get my fix, what time I was going to go to get it, I didn't enjoy being with my family ... [Ozzy, 22 years old].

2.1.3. The life I led involved getting the substance, using it and going home, that is, it was a triangle: Drugs, shoot up, home; drugs, shoot up and home or drugs, shoot up, and shooting gallery... Impotence is wanting and not being able, you want to stop using a substance but you cannot, because it is a physical dependence, not only mental, and you cannot ... Addicts are like the undead, we just walk around like zombies, we just think about drugs, we drug ourselves to live ... [Angel, 33 years old].

2.1.4. When I was using heroin, all my time was spent getting money, money to be able to use and I didn't work ... what I was paid was not enough for me to use, apart from having to ask for permission to get a fix and they got angry and I ran from work ... Before, all the time when I was drugged, I used to get money to be able to drug myself, and when I was not drugged, I was angry, I had withdrawal syndromes and I was in a bad mood ... Well, I was asleep all the time, anesthetized ... [Memo, 45 years old].

2.1.5. I also felt bad out there, you know, because I was also combining heroin and getting pills or crystal and ... Uhm, a series of things that ended very badly at the end, I had convulsions... [Junior, 42 years old].

2.1.6. For me that is hitting rock bottom... spiritually and morally you are down, and you can't get any further down. The moment you hit rock bottom, you start thinking ... or you ask yourself, a question that is very painful ... "When will all this gonna end?" [Angel, 33 years old].

2.1.7. The times I have left a rehabilitation center I have used again, for the same reason, due to depression, family problems, personal problems, I have relapsed [Eagle, 31 years old]
Axis: Social and normative integration

2.2.1. At least I'm not on the street [Nicté, 28 years old].

2.2.2. I lived in the street, going hungry, eating garbage, asking for money, putting out my hand, I did all that, many things, I prostituted myself with homosexuals and so on ... [Junior, 42 years old].

2.2.3. Three times they deported me and I went back ... And they separated me from my child, he was about six years old ... Not because I had committed a crime, just because I was Mexican [Rogelio, 45 years old].

2.2.4. Once my father beat me about a hundred and twenty times, when I was ten... I experienced all that and it made me very nervous ... At home there was never moral help, just scorn: "Get out of here, you bloody drug addict" ... [Meño, 45 years old].

2.2.5. When I was in a really bad state, I remember that once they took me to the penitentiary because of a fight I had and I was committing a crime with a person and I cut him with a knife and they took me away... and in there they were also killing me, in there ... [Juan, 36 years old].

2.2.6. My mother didn't believe me anymore, she didn't want to bring me here anymore. On the contrary, she gave me money: "Here, take it so that you can go and screw yourself up, as you wish, rather than lying to me ..." [Johnny, 39 years old].

2.2.7. Before they used to stop me there, near 20 Street, because I was much skinnier, and my appearance was more ... Before there were more arguments, disagreements, you know? They got angry because I was using, you know? and one way or another they tried to get my attention or tell me to stop now, and then I couldn't ... I couldn'y get inside, like that, in other institutions and I went out and used again and ... I could n't communicate properly with them ... [Memo, 45 years old].

2.2.8. I had inferiority complexes, I had fears deep inside me, insecurities, something that would not let me move ... Uhm, I went to a job ... Uhm, I asked for a job and I felt inferior to the person and especially if the person was trained, or had a degree, uhm, I didn't feel I was up to their level ... [Junior, 42 years old]. vation and social stigma, share the same sense of exclusion, so they can be assigned to a common thematic axis. Thus, from the same background of treatment, it is possible to infer two axes of thematic articulation which, as will be seen below, are valid in the description of the three remaining phases of the process. The first refers to addiction and dealing with substances; the second, to integration into conventional normative society. Consequently, the analysis of the following phases of the process is carried out considering its link with these two thematic categories, which would therefore operate as transversal axes.

\section{Relationship with the therapeutic system}

The second sequence comprises the initial contact with the MMDT and refers to the way the interviewees define the relationship they establish with the therapeutic system.

From the perspective of addiction and substance handling, two opposing discursive fields are formulated. The first involves the question of medication and the pharmacological effects of methadone ("something that touches your brain"), which are given positive connotations and postulate a relationship between taking drugs in regulated doses and obtaining positive results: "being well," "going out looking clean" (Table 3, segments 3.1.1 to 3.1.5); the second raises the problem of being "tied" to the program (3.1.6) and of developing an addiction to methadone (3.1.7), including the expectation of reducing the dose in order to be "independent" (3.1.8).

With regard to the axis of normative integration, one can also see the formation of two semantic-discursive fields, in this case of a complementary nature. In the first place, there is a description of the availability of the service in terms of "open doors" and "feeling attended" (3.2.1), as well as the characterization of the treatment received in terms of adjectives such as "professional," "disinterested," "decent," "humane," "kind," and "respectful" (3.2.2 to 
Table 3

Segments associated with the relationship with the therapeutic system

Axis: Addiction and dealing with substances

3.1.1. When I arrived, I started taking methadone and looked at the effects it has and how it affects you and how many times you have to take the medication ... and it has helped me stop. [Eagle, 31 years old].

3.1.2. We are seeing what dose they are going to give me, they gave me 70 , but it was a bit high for me and made me dozy ... right now they are reducing it, to see if they can bring it down to 50 to see how I feel, I think it's going be fine ... [Ozzy, 22 years old].

3.1.3. And the doctor told me, more or less, how to stop taking the diazepam ... to get clean [Rogelio, 45 years old]

3.1.4. With methadone I do not feel very doped or anything, I feel very good, I do not feel like using heroin or anything like that [Smiley, 33 years old].

3.1.5. Methadone has helped me in that I haven't used again, I feel good, I feel I don't need a dose to be able to work, with methadone I can do it, I can be active all day, without having to use a dose and it makes me feel good ... [Eagle, 31 years old].

3.1.6. I feel tied, like I have to come every day, but that's okay ... [Ozzy, 22 years old].

3.1.7. Nicté [ 28 years] has spent nearly 10 years in methadone replacement therapy and is concerned about the addiction she now has to this substance, because the withdrawal symptoms are worse than those for heroin. It is more difficult to give up using methadone, especially when you have been using it for a long time.

3.1.8. What I sometimes say is that they don't lower the dose, every so often, I think they should lower the dose, you know? ... Uhm, you have to come to the therapies here, but there are times when you can't ... And when it's the month when they are supposed to reduce your dose, they don't reduce it... I think it should be like that, they should reduce the dose every month, so that you can finish the program faster [Memo, 45 years old].
Axis: Social and normative integration

3.2.1. Here I have always been treated well, with the doors open ... I come every day for my dose, early, see the doctor, the doctor checks me, asks how I feel ... They treat me well, there are psychologists, I have group therapy ... I like the things here, they look after you, it's chill ... [Ozzy, 22 years old].

3.2.2. I am very grateful to all the people who have helped me here, mainly because they have been selfless ... You know, I don't pay anything, I'm not required to pay... And I'm very grateful to them because they have had a lot of patience and they have helped me a lot [Junior, 42, years].

3.2.3. The doctors are very kind, the psychologists, the psychiatrist ... They know their work, they are very well trained ... They have been very attentive and have behaved very well [Johnny, 39 years old]

3.2.4. We need people like them and they also become like your ... your friend, someone who understands you or when you need help with a problem or advice, they give it to you without asking for anything in return, and then you see they take the time to talk to you, they explore your life, I tell you, and then you see that there is understanding and they are giving you a hand ... [Eagler, 31 years old].

3.2.5. I have felt very supported and I feel that somebody cares for me and I see that they pay a lot of attention here and, the truth, uhm, they worry ... They ask how I am, my therapist always has time for me, always ... [Smiley, 33 years].

3.2.6. Here they treat us like people, like human beings, they treat you like they don't treat you anywhere else, you know? Sometimes as an addict you can feel humiliated ... Then you come here and they give you care you didn't expect, and then, you don't know what to do, in the beginning you don't know what to do [Ángel, 33 years old].

3.2.7. They treat you well, as a person, and in other places they do not treat you like that because you are an addict, you know? They discriminate against you ... [Memo, 45 years old].

3.2.8. The doctors are interested in you, often your family isn't interested in you but they are ... and that is why it's good, because I can tell when someone is interested in me ... They are people you can trust ... [Meño , 45 years old].

3.2.9. We need like a map or a plan, a guide ... How should we continue the treatment ... what to do tomorrow or after you leave here. You take your first steps, like that, you learn to be a baby, you know? And if they just let you loose, you will trip. And once you have the information, you know where to go, what steps to take ... [Eagler, 31 years old].
3.2.4). This positive evaluation of the relations established in the therapeutic context intersects with a second domain, of "undoing labeling," through notions such as "acceptance," "support," and "tolerance" that define the attitude adopted by the therapeutic team (3.2.5) and contrast with the previous experience of rejection, thus reversing the fear of being once again subject to stigmatization (3.2.6 and 3.2.7). The effect attributed to undoing labeling is associated with feelings of understanding and trust (3.2.8).

On the other hand, an expectation of guidance was also recorded, expressed explicitly by one of the participants and denoting the establishment of a relationship of dependency on the therapeutic system (3.2.9).

\section{Adjustment process in the treatment environment}

Based on the relationship established with the therapeutic system, various issues associated with the actions and mea- sures adopted are displayed, as part of the treatment process, to achieve change.

Regarding the issue of addiction and substance use, the main effects of methadone are cited as being on subjective well-being and adjustment capacity (Table 4, segment 4.1.1), which seem to be attributed, without any mediation, to the effectiveness of the medication alone. However, they are also linked to the need to learn and to develop skills to "be able to walk without a cane" (4.1.2), which could be associated with the expectation of guidance. Other elements include the need to strictly adhere to methadone administration and the benefits of participating in other components of the program: individual psychotherapy and group and family therapy (4.1.3 to 4.1.5). According to the respondents, participating in the program, without restricting themselves to taking the medication, provides the possibility of understanding the meaning of the treatment (4.1.6). 
Table 4

Adjustment process in the treatment environment

\begin{abstract}
Axis: Addiction and dealing with substances
4.1.1. Methadone removes all the discomforts and lets me do more things, like working ... [Johnny, 39 years old]

4.1.2. It's as if you had grabbed hold of a cane and used it for twenty years, and the doctor says: "The time has come for you to let go of the cane", and you are so used to it that you do not know how to walk without it. So, here they are preparing me so that I can walk without it ... [Angel, 33 years old]
\end{abstract}

4.1.3. I almost never miss a meeting, I try to go to all the therapies and to medicate too, almost every day I come, it's rare when I don't come for my medication. Yes, I try to come every day and to take the program as it is, to stick to the program [Meño, 45 years old]

4.1.4. Since I've been here, I haven't missed the meetings ... If you don't come or if you don't stop using, they don't adjust the dose... That has worked for me, I was at 80 and right now I'm at $30 \ldots$ I come to all the meetings and all this also counts here, including how they see you and whether you make an effort. Coming to the meetings and all that, all that counts also because a lot of people just come to medicate and leave ... [Juan, 36 years old]

4.1.5. I decided to be admitted to finish the program because I couldn't come to the therapies, that's why they didn't lower my dose and now that l've been admitted I go to my therapies and everything ... [Johnny, 39 years old]

4.1.6. Everything has a reason, a meaning: so we reconnect with our families [Junior, 42 years old]

\section{Axis: Social and normative integration}

4.2.1. You find out how you should deal with your feelings, what things are going to happen, like when you were anesthetized ... it's different, you know? [Eagle, 31 years old]

4.2.2. You start to realize many things ... [Juan, 36 years old]

4.2.3. I'm already understanding more things that I didn't understand ... They explained why [drugs are used], as a way of escaping from reality ... l've been hearing stories of people who are in the same situation as me and I see myself reflected in them, everything I dragg, all my grudges and bad thoughts ... [Johnny, 39 years old]

4.2.4. That's where you have to do the work, and one of the most difficult things is the work you do on yourself... The point is to work with your emotions ... I open my eyes and see the positive things in life, not the negative ones like I used to... That's my goal, first, to be well, second, to have the motivation to be well, third, to have the motivation to get up, bathe and do what you have to do [Ángel, 33 years old]

4.2.5. I've examined a lot of the things I have inside me and I'm beginning to find out why I started taking drugs... I'm beginning to find out many things I didn't know about myself ... I used to get angry... And l'm already starting to find the peace I wanted [Johnny, 39 years old]

4.2.6. I can handle my emotions differently because I know I'm not under the influence of a drug and that I'm now starting in a clean, drug-free way ... When you come out of the group meeting, you come out with your batteries recharged and your self-esteem rises and it is not as low as when you have no-one to listen to or your pals ... [Eagler, 31 years old]

4.2.7. Before I couldn't interact the way we are doing right now, I used to get tongue-tied, and right now I feel like I'm more self-confident, and that I have less complexes than I used to [Junior, 42 years old].

4.2.8. I've been thinking things over and what I did wasn't good ... What l'm planning to do now is think about the future, live well, and look for a job, I want to see my family and behave properly.. [Juan, 36 years old]

4.2.9. They make you be responsible, and have a routine ... Right now I'm doing things very differently, really, I try and do what I didn't do before, which are good things. Because before, I just used to do damage, I was harming my family... the people I had around me, like a source of infection... That's what I am changing now [Junior, 42 years old]

4.2.10. In the program they teach you more than anything else to develop and to know how to control yourself ... in the way you control your impulses [Smiley, 33 years old]

4.2.11. When I got here, I started to open my eyes, I started to use what my family had taught me, I started using manners, caution and honesty ... I started doing other things, and doing exercise, I began walking in the park, I started to appreciate life in a different way ... The information that I was given here ... [about] what I should do ... [Ángel, 33 years old]

4.2.12. Right now I don't feel bad anymore when I talk to other people, sometimes you can't... You get used to using swear words, you come out with swear words. And so I started to get used to talking to other people and so on when I go to work or whatever, I know how to communicate well with other people so that they have a good opinion of you... [Juan, 36]

4.2.13. It also means that the family has to get involved in the program, so that they know how everything works and particularly how to treat an addict ... [Smiley, 33 years old]

4.2.14. When I came to family therapy with my mom, they really helped me communicate with her, and with my dad too and so on... [Ozzy, 22 years old]
The effort made in the treatment to achieve the purposes of social reintegration encompasses several other thematic fields or spheres of action. A first action that could be considered a point of support for the development of this sequence is "giving oneself time" or "giving the process" time. This triggers a triple process of cognitive change ("realizing"), affective change ("internal work") and normative adjustment (which can be summarized as "learning to control oneself"). The field of meanings of "realizing" includes, first of all, becoming aware, the perception of having a prob- lem, and the aim of informing oneself about the process of change (4.2.1) to achieve understanding (4.2.2). and 4.2.3); "understanding" the implications of heroin use, the reasons for beginning to use it, the meaning of treatment, and recognizing the true intentions of the family in encouraging the interviewees to seek treatment, and "things about myself," affects and fears, "grudges and bad thoughts" (4.2.3).

Affective change includes an effort to undertake internal work (4.2.4) which, following the catharsis, "shogging off many things about myself", can lead to an affective 
Table 5

Segments related to the process of social reintegration

Axis: Addiction and dealing with substances

5.1.1. We shouldn't go to places where there are people... where there is a lot of drugs and prostitution ... Before, all my friends were people who used drugs and ... it is easier for them to drag me to use drugs than for me to bring them onto my side... Now, uhm, I look for a different kind of friends... I prefer to stay home [Junior, 42 years old]

5.1.2. I began to stop going to the places I used to go to, I started to get new friends, to change going to places that did not lead to anything ... [Ángel, 33 years old]

5.1.3. I see people doin' it on purpose, because when they look at you like that, they don't invite you, not a peso, nothing. But if they see you are clean, they want to see you defeated, and I say it's the devil at work ... They want to offer you drugs, they want to see you beaten ... [Rogelio, 45 years old]

5.1.4. I kept seeing the same people, I kept the same kind of company, I went everywhere with my buddies ... I went on flirting with drugs, I kept meeting with the same people and that was what affected me [Ozzy, 22 years]

5.1.5. Now that I'm awake ....and that I can look around, I can work without drugs, without infection from a contaminated syringe, all that ... Now with this medication, I don't have to use contaminated needles or ones that have been used by someone else who may have AIDS or some other disease ... [Eagle, 31 years old]

5.1.6. People don't talk about it much but they do know I have an illness ... I don't know, they ignore the subject, just as if it had not happened, as if it were already a new chapter, as if I were just a new person and... [ Ozzy, 22 years old]

5.1.7. I don't know how to handle this with my daughters. The youngest one is the one who asks questions. I don't give them explanations ... but one day they will find out, won't they? I would prefer it if they never found out ... [Nicté, 28 years old]

\section{Axis: Social and normative integration}

5.2.1. I feel that I can work so that I can lead a responsible life and contribute to the household expenses... pay the bills, utilities, water, electricity ... [Rogelio, 45 years old]

5.2.2. Right now I am not anesthetized, I can see what is happening around me and inside me ... When I was anesthetized, I had lost many things, even emotions. And now my emotions are really strong, now I really feel things the way they are ... A feeling towards something that is real while not being anesthetized ... [Eagler, 31 years old]

5.2.3. I can interact more, I am more receptive, and I pay more attention to everything and I feel less pressured and have no cold turkey... [Smiley, 33 years old]

5.2.4. Now I talk more to my family and cousins. I hadn't spent time with them for a long time and now it's better ... I feel calm, without the anxiety of what I'm going to use or that I'm going to feel bad or afraid ... I'm doing well, I'm calm ... [Ozzy, 22 years old ]

5.2.5. Several parts have improved: family, friends, work ... You do things you didn't do before [Rogelio, 45 years old]

5.2.6. Changes in my judgments and attitudes ... I see things differently, I have a better criterion, especially one that is not as negative as it was before, when everything looked bad [Eagle, 31 years old]

5.2.7. Now I brush my teeth, and change my clothes ... I'm gradually cleaning up my body [Junior, 42 years old]

5.2.8. I began to sleep for five minutes, half an hour and then all night ... And now I begin to wake up well, without nerves, or anything ... [Meño, 45 years old]

5.2.9. My physical appearance has improved and my hygiene too ... Now I can bathe, I clean myself up better and I like all that ... [Eagler, 31 years old]

5.2.10. Right now I'm a bit fatter, before I was very thin and scrawny [Rogelio, 45 years old] 5.2.11. On a normal day, I am at home and ... I talk a lot to the clerk in the store, I watch television ... very different from how I lived when I used heroin ... [Rogelio, 45 years old]

5.2.12. And when they see you look well, and see the change, and that you're freshly bathed and a bit chubbier, a bit fatter, and they see the changes, they treat you differently [Meño, 45 years old]

5.2.13. Now I have realized that they see me differently, they support me, many people open their doors to me, and offer me a taco or something ... Unlike before... because they didn't trust me [Juan, 36 years old]

5.2.14. I started talking to girls and ... I went out with a girl, my girlfriend. I started doing things that I wanted to before, many things became possible [Angel, 33 years old]

5.2.15. I've got closer to my family, I get along better with them, I spend more time with them ... I have two grandchildren and now I enjoy them, I play with them ... Because I never enjoyed my children because I have been using heroin for many years, and now I do enjoy them ... [Memo, 45 years old]

5.2.16. My family is supporting me and so on ... I talk more with them, I spend more time around my family. I don't have to hide any more [Ozzy, 22 years old]

5.2.17. The relationship with my family has improved in terms of their being more trusting, more accepting of me, my behavior, my way of doing things ... [Eagle, 31 years old]

5.2.18. I began doing an honest job ... [Angel, 33 years old]

5.2.19. Now I just come and take my medication in the morning and I can work all day, you know, I can work ... [Memo, 45 years old]

5.2.20. Like people who are being reincorporated into society, because it's good to be busy at work a certain number of hours a day, and then to go home and rest and do the things you have to do. Well, like everything, you know? It's important to have a job [Eagle, 31 years old] change primarily identified as the achievement of peace of mind, motivation to change and enhanced self-esteem (4.2.4 to 4.2.6). Likewise, emotional work or that involving "internal complexes" is associated with the modification of attitudes and the building of new skills (4.2.7).
Third, adjustment in the context of treatment implies the possibility of learning to control oneself and to function, presumably within conventional society (4.2.8). It also means reconsidering and assuming responsibility, in a broad sense that implies reciprocity to others, as well as 
restoring balance, mainly in the family, by adjusting habits and lifestyles, all of which contributes to the possibility of new identity definitions (4.2.9).

In the same way, it expresses the possibility of thinking about the future, which is projected in the expectation of joining the conventional spheres of work and family (4.2.10), which, in some cases, invites them to recover lost values, learned in the family, useful for normative adjustment (4.2.11), or for developing adaptive skills to reverse the effects of exclusion, which show the main role that language and communication skills could have in the process (4.2.12).

Finally, the treatment process also involves the family, both in the sense of bringing it closer to the patient's problem (4.2.13) and in bringing the latter to new forms of rapprochement (4.2.14).

\section{Social reintegration}

This phase points to the outcome of the process. The emphasis is on the conditions of the external environment, which, however, reflect the efforts and attempts to change made within the therapeutic process.

Concerning addiction and dealing with drugs, the main issue is the redefinition of the relationship with them, a field in which respondents specifically raise the issue of avoidance. First of all, they mention avoiding drug abuse networks and areas where drugs are available, which is linked to the search for new friendships and the formation of new support networks within normative society, or confinement in the domestic sphere and social isolation (Table 5, segments 5.1.1 to 5.1.3). This is due to the certainty of the risk of relapse (5.1.4), and the reduction of the risk of contagion (5.1.5). Silence around the issue of drugs in the family is also mentioned. (5.1.6 and 5.1.7).

Regarding the issue of incorporation into the normative environment, a couple of expressions are proposed as guiding ideas: leading a life like that of "normal" people and taking responsibility, with a clear imperative connotation (5.2.1). However, one of the issues that is consistently identified is coming out of anesthesia, "reconnecting" and "feeling again." It is not only a question of recovering the ability to enjoy and experience affects (5.2.2) but also of recovering the sensitivity of the body and opening up to the world and others. This experience refers to a new state of well-being (5.2.3) and tranquility (5.2.4). Concomitantly, there is a perception of improvement (5.2.5) that refers to both the ability to reinsert oneself into an institutional setting, and to establish significant interpersonal relationships. All these can be linked to the adoption of positive attitudes (5.2.6) and normative expectations.

Among the factors pointing to change, the respondents cited health care and its effects: "Cleaning up the body," "Waking up without feeling nervous" (5.2.7, 5.2.8), changing their physical appearance and body image (5.2.9, 5.2.10), as well as changing their habits and lifestyles
(5.2.11). At the same time, there is a recognition of a change in attitudes among people around $(5.2 .12,5.2 .13)$ which in some way, lends continuity, in the external environment, to the undoing of labels. The perception of this change ("being seen differently") reinforces feelings of acceptance, validation, and support. Finally, there is a development or recovery of social and communication skills, which permits rapprochement with representatives of the dominant society. It also involves the basic interaction skills required to chat up a girl (5.2.14), take part in a job interview, or engage in conversation with people regarded as being from a higher class. With regards the social spaces in which the reintegration process takes place, the first thing is the importance given to the family, with which a re-encounter takes place, allowing the re-establishment of acceptance, trust, and mutual care (5.2.15 to 5.2.17). The work sphere also plays an important role in the process of the "normalization" and development of regulatory mechanisms (5.2.18 to 5.2.20), as does going back to school and joining religious groups.

\section{DISCUSSION AND CONCLUSION}

The analysis undertaken reveals the predominance of narratives with a typical structure that coincide with those identified some time ago by structural analysis (Barthes et al., 1972) and sociology (Labov, 1972). This narrative structure makes it possible to give a pattern, shape, and meaning to the experience of normative adjustment, tracing an upward trajectory characteristic of a progressive narrative of achievement and improvement (Gergen, 2007), with a strong psychosocial content.

Accordingly, this paper allows an approach to "emic" elements of experience (Albertín Carbó, 2000) that yields thematic spheres referring to a process of social and normative adjustment. Without being exhaustive, we can highlight the following:

- The problem of drug use and the relationship with substances. Despite being in a process of reconfiguration, this issue is not necessarily resolved, leading to avoidance and concealment strategies with a high psychosocial cost. These aspects have been highlighted by López Torrecillas, Peralta, Muñoz Rivas, and Godoy (2003) and Rodríguez Kuri, Córdova Alcaráz, and Fernández Cáceres (2015).

- The social rejection, outcasting, and precariousness, which place the heroin addict in a particular condition of vulnerability. Regardless of whether social exclusion is considered an antecedent or a consequence of drug consumption, it involves a complex combination of interrelated problems such as unemployment, low economic income, loss of skills, the erosion of support networks, exposure to violence, and the breaking of balance in 
family and other institutions (March, Oviedo-Joekes, \& Romero, 2006; Epele, 2010). In Mexico, Fleiz and collaborators have documented factors of this nature associated with exclusion (Fleiz et al., 2019). Disaffiliation and social exclusion combine the effects of psychosocial deprivation, invalidation and rupture of primary integration networks, which lead to the loss of a socially recognized place (Castel, 1997).

- The experience of undoing labeling and gaining acceptance and recognition, to which, according to the testimonials of the respondents, we must grant a central place at the beginning of the treatment and process of change. It implies putting the incidence of relational and interpersonal factors in first place, in accordance with Rubio Arribas (2001) and Pascual Mollá and Pascual Pastor, (2017).

- The importance given to the experience of "reconnecting" and "feeling again" which, from a subjective perspective, allows to attribute meaning to the reestablishment of a place in the world, enabling the subject to aspire to recognize himself as a human being with full rights, with the capacity for self-observation, becoming closer to others, and having agency over reality (Krause et al., 2006).

- Self-care and the development of "lifestyles" and skills for interaction as a twofold strategy of normative adjustment within the dominant framework of normality, including, in particular, linguistic and communication skills for interaction with representatives of the conventional society. That is to say, work with and on oneself, which has been considered the foundation of the ethical subject (Foucault, 1984).

- The naturalization of a stereotyped representation of the family and of the means of adjustment (incorporation into educational, work, or religious institutions), which reflects the dominance of relatively rigid conventional adaptation imperatives (Rodríguez-Kuri \& Fernández Cáceres, 2014; Osuna Díaz, 2013).

Based on these findings, we can emphasize the advisability of making the treatment approach more flexible, in order to accompany and reinforce the reintegration process without providing scope for the reproduction, from the therapeutic system, of new forms of dependence or abuse (Albertín Carbó, 2000). Our study shows the importance of incorporating psychotherapeutic components that offer integral adjustment alternatives and encourage the broad participation of patients.

Within the therapeutic context, it is worth mentioning the suitability of alternative approaches aimed at the per- son and not exclusively focused on the addictive process (Brands, Blake, \& Marsh, 2003), adapted to the particular needs of each patient, strengthening the socially validated effect of acceptance and recognition that seems to be a central aspect of the patients' experience.

It is also advisable to develop care strategies that permit closer links between the therapeutic system and the environment, in order to more effectively remove the mechanisms of exclusion and stigma that usually continue operating, as well as to reverse the "deviant" affiliation of those affected (Singh et al., 2014; Verster et al., 2003).

It is also possible to recommend the development of follow-up or accompaniment strategies that will enable the process of change in the external environment to continue, in order to address the relationship between exclusion and relapse conditions. In this respect, it should be noted that the lack of knowledge of both the relational dimensions of reintegration and the suffering associated with exclusion can play a decisive role in the persistence of substance use (Harris et al., 2006; March et al., 2006; Verster et al., 2003).

It is also possible to implement harm reduction programs that imply a different perception of the patient and their needs, such as safe injection rooms, the provision of naltrexone or naloxone to cope with an overdose crisis, and the distribution of methadone for external administration (Priest et al., 2019; Brands et al., 2003; Gutwinski et al., 2013).

Moreover, the implementation of programs must be based on the development of public policies that not only consider the problem of poverty and social and economic precariousness (Verster et al., 2003), including aspects such as access to employment, housing, and dignified salary, but also aspects such as the response of structures in normative society to addicts' attempts at reintegration.

From a methodological point of view, all of the above results point to the advisability of using indicators sensitive to the various components of the reintegration process in the evaluation of programs, beyond a purely functionalist vision focused on aspects such as obtaining employment or a reduction of antisocial behavior (March et al., 2006).

To conclude, we point out some limitations of this paper. As any exercise of elucidation of the meaning of experience, the one carried out in this work does not constitute but a set of conjectural hypotheses of a material that, from other angles and at other moments, could undoubtedly offer other reading perspectives. Limitations also include those of a qualitative design, which limits the generalization of findings or refers to the specific characteristics of the population segment from which the sample was drawn. One aspect that warrants further exploration, for instance, is the conditions of acute disaffiliation and exclusion that are likely to affect social groups such as women addicts, HIV patients, migrants, and ex-convicts (Joseph et al., 2000; UNODC, 2018). 


\section{Funding}

None.

\section{Conflict of interest}

The authors declare they have no conflicts of interest.

\section{Acknowledgements}

We would like to thank Raúl R. Palacios for his support in carrying out this work and Sara E. García Gutiérrez de Velasco for sharing some significant clues for the analysis of cases.

\section{REFERENCES}

Agamben, G. (2010). Signatura rerum, Sobre el método. Barcelona: Editorial Anagrama. ISBN: 978-84-339-6305-05

Albertín Carbó, P. (2000). La perspectiva de los usuarios en un programa de mantenimiento con metadona: Elementos evaluativos. Intervención Psicosocial, 9(2), 217-231

Aronson, J. (1995). A pragmatic view of thematic analysis. The Qualitative Report, 2(1), 1-3. Retrieved from: https://nsuworks.nova.edu/tqr/vol2/iss 1/3

Bal, M. \& Van Boheemen, C. (2009). Narratology: Introduction to the theory of narrative. Toronto: University of Toronto Press. ISBN: 978-0-8020-9631-9

Barthes, R., Greimas, A. J., Bremont, C., Gritti, J., Morin, V., Metz, C., Todorov, T., \& Genette, G. (1972). Análisis estructural del relato. Buenos Aires: Editorial Tiempo Contemporáneo.

Brands, B., Blake, J., \& Marsh, D. (2003). Impact of methadone program philosophy changes on early treatment outcomes. Journal of Addictive Diseases, 22(3), 1938. doi: 10.1300/j069v22n03_03

Braun, V. \& Clarke, V. (2006). Using thematic analysis in psychology. Qualitative Research in Psychology, 3(2), 77-101. doi: 10.1191/1478088706qp063oa

Bruneau, J., Ahamad, K., Goyer, M. Ė., Poulin, G., Selby, P., Fischer, B., ... \& Wood E. (2018). Management of opioid use disorders: A national clinical practice guideline. Canadian Medical Association Journal, 190(9), E247-E257. doi: 10.1503/cmaj. 170958

Castel, R. (1997). La metamorfosis de la cuestión social. Una crónica del salariado. Barcelona: Editorial Paidós.

Castro, E. (2012). Cuestiones de método: La problemática del ejemplo en Foucault y Agamben. Res Publica: Revista de Filosofia Política, (28), 53-75. ISSN: 1576-4184

Coffey, A. \& Atkinson, P. (2003). Encontrar el sentido a los datos cualitativos. Estrategias complementarias de investigación. Medellín, Colombia: Editorial Universidad de Antioquia.

Creswell, J. (2007). Qualitative inquiry and research design. Choosing among five approaches. Thousand Oaks: Sage Publications. ISBN: 97-8-1-4129-1607-3

Epele, M. (2010). Sujetar por la herida, una etnografia sobre drogas, pobreza y salud. Buenos Aires: Editorial Paidós. doi: 10.1590/S1984-64872011000200011

Farías, L. \& Montero, M. (2005). De la transcripción y otros aspectos artesanales de la investigación cualitativa. International Journal of Qualitative Methods, 4(1), 53-68.

Fernández Miranda, J. J. (2005). Efectividad de los programas de mantenimiento con metadona. Adicciones, 17(2), 167-180. ISSN: 0214-4840

Fleiz, C., Domínguez, M., Villatoro, J. A., Vázquez, F., Zafra, E., Sánchez, ... \& Medina-Mora, M. E. (2019). Cuqueando la Chiva, Contextos del consumo de heroína en la frontera norte de México. Ciudad de México, México: Instituto Nacional de Psiquiatría Ramón de la Fuente Muñiz. ISBN: in process.

Foucault, M. (1984). Historia de la sexualidad 2, El uso de los placeres. México: Siglo XXI Editores.

Gergen, K. (2007). La autonarración en la vida social. En: Estrada, A. \& Diazgranados S. (Comp.), Construccionismo social, Aportes para el debate y la práctica. Bogotá, Colombia: Ediciones Uniandes. p 153-188.

Gutwinski, S., Bald, L. K., Heinz, A., Müller, C. A., Schmidt, A., Wiers, C., ... Gallinat, J. (2013). Take home maintenance medication in opiate dependence. Deutsches Ärzeteblatt International, 110(23-24), 405-412. doi: 10.3238/arzteb1.2013.0405

Harris Jr, K. A., Arnsten, J. H., Joseph, H., Hecht, J., Marion, I., Juliana, P., \&
Gourevitch, M. N. (2006). A 5-year evaluation of a methadone medical maintenance program. Journal of Substance Abuse Treatment, 31(4), 433-438. doi: 10.1016/j.jsat.2006.05.018

Joseph, H., Stancliff, S., \& Langrod, J. (2000). Methadone maintenance treatment (MMT): A review of historical and clinical issues. The Mount Sinai Journal of Medicine, 67(5-6), 347-364.

Khalatbari-mohseni, A., Banafshe, H. R., Mirhosseini, N., Asemi, Z., Ghaderi, A., \& Omidi, A. (2019). The effects of crocin on psychological parameters in patients under methadone maintenance treatment: a randomized clinical trial. Substance Abuse Treatment, Prevention, and Policy, 14(1), 9. doi: 10.1186/s13011-019-0198-1

Krause, M., De La Parra, G., Arístegui, R., Dagnino, P., Tomicic, A., Valdés, N., ... Ramírez, I. (2006). Indicadores genéricos de cambio en el proceso psicoterapéutico. Revista Latinoamericana de Psicología, 38(2), 299-325. ISSN: 0120-0534

Labov, W. (1972). The transformation of experience in narrative syntax. In W. Labov (Ed.). Language in the inner city. Filadelfia: University of Pennsylvania Press. p 354-396.

López Torrecillas, F., Peralta, I., Muñoz Rivas, M. J., \& Godoy, J. F. (2003). Autocontrol y consumo de drogas. Adicciones, 15(2), 127-136. doi: 10.20882/ adicciones. 436

March, J. C., Oviedo-Joekes, E., \& Romero, M. (2006). Drugs and social exclusion in ten European cities. European Addiction Research, 12(1), 33-41. doi: 10.1159/000088581

Mattick, R. P., Breen, C., Kimber, J., \& Davoli, M. (2009). Methadone maintenance therapy versus no opioid replacement therapy for opioid dependence. Cochrane Database of Systematic Reviews, 8(3), CD002209. doi: 10.1002/14651858. CD002209.pub2

Mieles Barrera, M. D., Tonon, G., \& Alvarado Salgado, S. V. (2012). Investigación cualitativa: el análisis temático para el tratamiento de la información desde el enfoque de la fenomenología social. Universitas humanistica, (74), 195-225. ISSN: 0120-4807

Osuna Díaz, M. M. (2013). Estigma social en madres puertorriqueñas usuarias de heroína: Una exploración de las voces femeninas y su entorno social. Revista Puertorriqueña de Psicología, 24, 1-18. ISSN: 1946-2026

Pascual Mollá, M. \& Pascual Pastor, F. (2017). El estigma en la persona adicta. Adicciones, 29(4), 223-226. doi: 10.20882/adicciones. 1038

Priest, K. C., Gorfinkel, L., Klimas, J., Jones, A., Fairbairn, N., \& McCarty, D. (2019). Comparing Canadian and United States opioid agonist therapy policies. International Journal of Drug Policy. doi: 10.1016/j.drugpo.2019.01.020

Rodríguez-Kuri, S. E. \& Fernández Cáceres, M. C. (2014). Inserción social de usuarios de drogas en rehabilitación. Un estudio cualitativo. Revista de Psicología: Universidad de Antioquía, 6(2), 57-78.

Rodríguez Kuri, S. E., Córdova Alcaráz, A. J., \& Fernández Cáceres, M. C. (2015). Estudio comparativo del proceso de inserción social en hombres y mujeres usuarios de drogas en rehabilitación. Salud y drogas, 15(1), 49-54. ISSN: 1578-5319

Rubio Arribas, F. J. (2001). Proceso de construcción de un estigma: La exclusión social de la drogadicción. Nómadas. Revista Crítica de Ciencias Sociales y Jurídicas, 4(2), 233-243.

Singh, P. M., Shrestha, D. M., \& Bhandari, G. P. (2014). A qualitative assessment of methadone maintenance therapy program in Nepal: Evidence to scaling up at national level. Nepal Medical College Journal, 16(1), 17-9.

Solal, J. F., \& Schneider, M. C. (1996). Toxicomanies et exclusion sociale: Pathologie de la précarité et de la misère. La revue du Praticien, 46(15), 1854-1860.

United Nations Office on Drugs and Crime. (2018). World Drug Report 2018. Vienna: United Nations Publications. Sales No. E.18.XI.9. ISBN: 978-92-1-148304-8

Verster, A. \& Solberg, U. (2003). Social reintegration in the European Union and Norway. Lisbon: European Monitoring Centre for Drugs and Drug Addiction (EMCDDA), 3. Retrieved from: http://www.emcdda.europa.eu/attachements. cfm/att_2156_EN_social_reintegration_eu.pdf

World Health Organization. Department of Mental Health, Substance Abuse, World Health Organization, International Narcotics Control Board, United Nations Office on Drugs, \& Crime. (2009). Guidelines for the psychosocially assisted pharmacological treatment of opioid dependence. World Health Organization. ISBN: 978-92-4-154754-3 